\section{O-41乾燥濾紙血を用いた新しいPSA測定キット の検討}

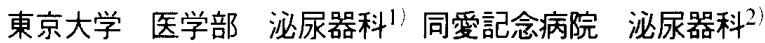 \\ 同愛記念病院 臨床検查部3.（株）エスアールエル4)

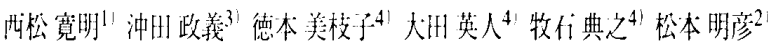

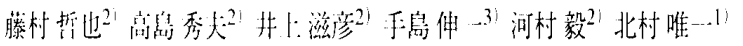

【緒、】PSA単独測定を一次検渗とした地域医師会・自治体による

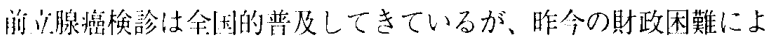
りその維持が淋難を来していることは成知の事実である。我々は か权てから㛟㹋コストを軽減川能なPSAキットの開発に関与して きたが、今回新しい滤紙血法で良好な結果を得たので報告する。 【对象】同爱記念病院を受的した男性30例(BPH17例、前立腺㿋13

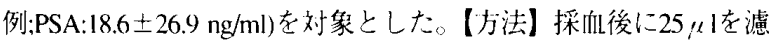

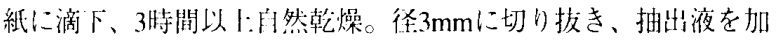
え8時間の抽计後に、E-プレート栄研PSAにて測定した。【結果】

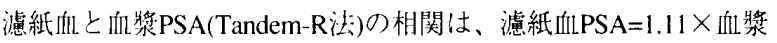
PSA倒 $+0.74\left(r^{2}=0.997\right)$ と非常に既好な結果を示した。再現性、希 秋試験、乾燥・保伱状態試験でも良好な結果を得た。【考察】検 渗に伴う検体集配コストはその規模に応して差が有るが、本法を 利月すれば、娭渗通知の際に受診㡂と共に滤紙を同封するたけで 次検衫が汀能となり、高いコストパフォーマンスが得らる。ま たその于軽さから、次検診受診獄の问上が期街できよう。さらに 本法はペプシノーゲン、ヘリコバクターピロリ抗体、般生化学

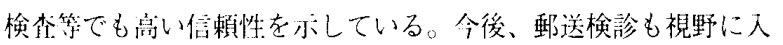
れた集恻検略の新しい.形態を提小寸るものとなるう。

PSA 滤紙 検診

\section{O- 42 限局性前立腺癌における高感度 P S A の有 用性の検討}

\author{
川崎医科大学 泌尿器科1)

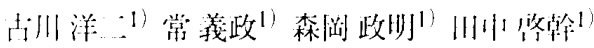

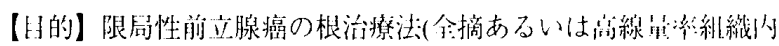

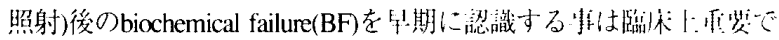

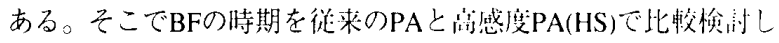

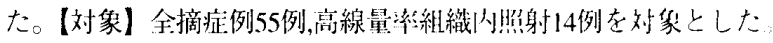
年齢は52-82歳(平均 67歳),族期はT1 12例, T2 40例, T3 15例.T4 2例で PA測定はTandem-R法,HS测起は米|EDPC社PA測起キット”イムラ イズ”を朋い同じ血清で測定した。BFの管我はPAで $0.2 \mathrm{ng} / \mathrm{ml}$

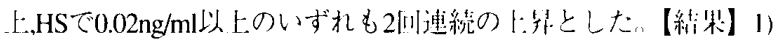

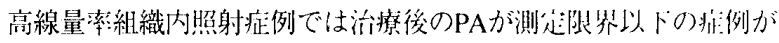
3例と少なく,HS測定の有用性は低いと思わ扎た。2)食摘将例では 経過中にPAが $0.2 \mathrm{ng} / \mathrm{ml}$ 以下に低下しなかった2例老除きPA.HSとも

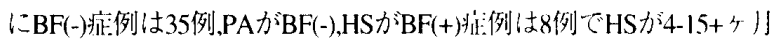

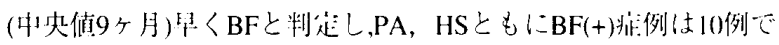
HSが0-18ヶ月(中央値6ケ月) 主く

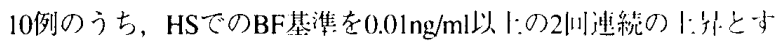

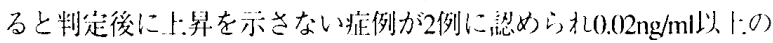
2[回連続の!:昇がBF基準として受当であった【紏喻] HS-PSA渔 定は前立腺全摘術後のbiochemical failure

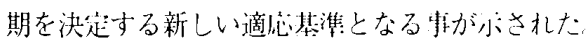

\section{高感度P S A 限局性前立腺癌 biochemical failure}

\section{O-43 前立腺癌の病理学的病期診断におけるPSA 関連マーカーの有用性}

\footnotetext{
慶應義熟大学 医学部 泌尿器科 ${ }^{1}$

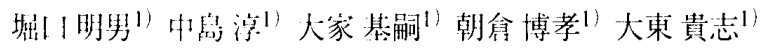

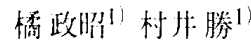

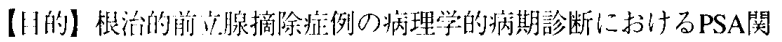
連マーカーの付椆性ににつき検討した。【刘象と方法】前立腺癌と 衫断し内分泌潦法抢よび放射線療法を施行せず根治的前立腺摘除 術を施行した64例を対象とした。病理学的病期と生検組織の Gleason score、癌陽性標本率、Prostate (P) volume、Transition volume (TZ) volume、自清PSA俻、Free/Total PSA ratio (F/T比)、PSA density (PSAD)、PSA transition zone density (PSATZD) との関連老検討した。 【絬果】64例的T2は47例、pT3は17例であった。pT2群のGleason score、PSA、PSAD、PSATZDは4.29 $\pm 0.21 、 13.78 \pm 3.11 \mathrm{ng} / \mathrm{ml}$ 、 $0.41 \pm 0.04 \mathrm{ng} / \mathrm{ml} / \mathrm{cc} 、 1.07 \pm 0.10 \mathrm{ng} / \mathrm{ml} / \mathrm{cc}$ であり、 pT3群 $(5.41 \pm 0.41$ 、 $15.81 \pm 2.69 \mathrm{ng} / \mathrm{ml} 、 0.63 \pm 0.09 \mathrm{ng} / \mathrm{ml} / \mathrm{cc} 、 2.07 \pm 0.45 \mathrm{ng} / \mathrm{ml} / \mathrm{cc})$ に比べ 份意に低值であった $(\mathrm{p}<0.05)$ 。癌隄性標本率、 $\mathrm{P}$ volume、TZ volume、F/T比は仵意差を諗めなかった。ROC分析に扔ける曲線下 面積はGleason scoreは0.751、PSAは0.631、PSADは0.698、PSATZD は0.695であった。ロジスティック回㷌分析ではPSATZD、Gleason score 6以上対6末満が病理学的病期と有意に関連する因子であっ た【絬棓】Gleason scoreとPSATZDが根洁的前立腺摘除症例の病理 学的狱期渗断の子测において有用である可能性が示唆された。 前立腺癌 PSA関連マーカー 病理学的病期
}

\section{O- 44 前立腺癌診断におけるPSA-ACTの有用性 に関する検討 - total PSA、free / total PSA比、 $\gamma$-SM / PSA比、PSADとの比較梌討}

\section{昭和大学 医学部 泌尿器科学教室}

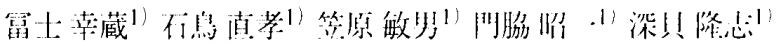

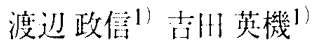

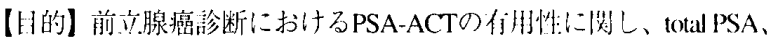
free/total PSA比 (F/T比)、 $\gamma$-SM/PSA比、PSADと比較樻到した

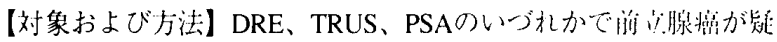
われ、 sextant biopsyを施行した135例を対象とした， total PSA、free PSA、PSA-ACTはそれぞれT andem-R PSA kit、Tandem-R free PSA kit、

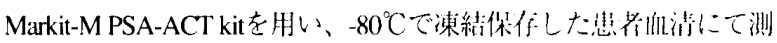

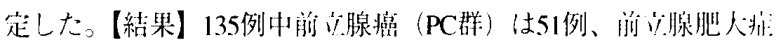

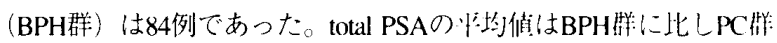
で有意に高値であった。PSA-ACT、F/T比、 $\gamma$-SM/PSAlt、PSAD の平均值も陆群間に们意等を認めた。しかし、ROC曲線に上る検 討では各検查法間に有意差を認めなかった。そこで、total PSA

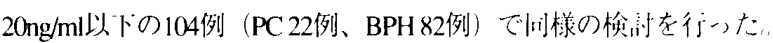
total PSAでは耐群間に有意着は認めなからたが、PSA-ACT、F/T比、

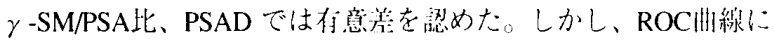

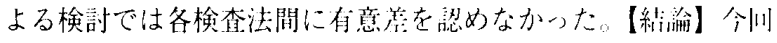
の検討ではtotal PSAが20ng/mI以下の壮例群でPSA-ACTはPSAより やや有用である问能性が示唆されたが、他のバラメーターと比脐

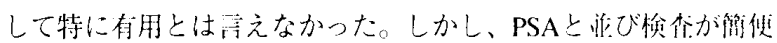
で安定性もあるため、さらに检沽の必装があると琹才机た 前立腺癌 PSA PSA-ACT 